\section{PENGAWASAN TERHADAP ORGANISASI KEMASYARAKATAN YANG DIDIRIKAN OLEH WARGA NEGARA ASING ${ }^{1}$ Oleh: Deicy N. Karamoy ${ }^{2}$}

\begin{abstract}
ABSTRAK
Penelitian ini dilakukan dengan tujuan untuk mengetahui Bagaimana pemerintah melakukan pengawasan terhadap organisasi kemasyarakatan yang didirikan oleh warga negara asing. Dengan menggunakan metode penelitian yuridis normatif, disimpulkan: 1 . Pengawasan terhadap organisasi kemasyarakatan yang didirikan oleh warga negara asing dilakukan untuk meningkatkan kinerja dan akuntabilitas ormas yang didirikan oleh warga negara asing maka dilakukan pengawasan internal dan eksternal. Pengawasan internal terhadap ormas yang didirikan oleh warga negara asing dilakukan sesuai dengan mekanisme organisasi yang diatur dalam anggaran dasar/anggaran rumah tangga. Pengawasan eksternal dilakukan oleh masyarakat, pemerintah, dan/atau pemerintah daerah. 2. Pelaksanaan pengawasan terhadap organisasi kemasyarakatan yang didirikan oleh warga negara asing memerlukan dukungan masyarakat melalui upaya berupa pengaduan yang dapat disampaikan kepada pemerintah atau pemerintah daerah, apabila diketahui ada organisasi kemasyarakatan yang didirikan oleh warga negara asing melakukan pelanggaran atas ketentuan-ketentuan dalam UndangUndang Nomor 17 Tahun 2013 Tentang Organisasi Kemasyarakatan.
\end{abstract}

Kata kunci: Pengawasan, Organisasi Kemasyarakatan Yang Didirikan, Warga Negara Asing

\section{PENDAHULUAN}

\section{A. Latar Belakang}

Penjelasan Peraturan Pemerintah Pengganti Undang-Undang Nomor 2 Tahun 2017 Tentang Perubahan Atas Undang-Undang Nomor 17 Tahun $2013 \quad$ Tentang Organisasi Kemasyarakatan Menjadi Undang-Undang, wujud dari bunyi alinea keempat undangUndang Dasar Negara Republik Indonesia Tahun 1945, antara lain telah dicantumkan di dalam Pasal 28 Undang-Undang Dasar Negara

\footnotetext{
${ }^{1}$ Artikel

${ }^{2}$ Fakultas Hukum Unsrat, Doktor IImu Hukum
}

Republik Indonesia Tahun 1945 yang menyatakan bahwa kebebasan berserikat, berkumpul, dan mengeluarkan pendapat merupakan bagian dari hak asasi manusia dalam kehidupan berbangsa dan bernegara dalam Negara Kesatuan Republik Indonesia.

Ketentuan untuk melaksanakan Pasal 28 Undang-Undang Dasar Negara Republik Indonesia Tahun 1945 Pemerintah telah mengundangkan Undang-Undang Nomor 17 Tahun 2013 tentang Organisasi Kemasyarakatan dan Undang-Undang Nomor 9 Tahun 1998 tentang Kemerdekaan Menyampaikan Pendapat di Muka umum. Di dalam kedua Undang-Undang tersebut telah dicantumkan hak-hak setiap warga Negara sebagai bentuk perlindungan Pemerintah terhadap hak d.sasi manusia (HAM). Namun demikian, di dalam rangka perlindungan hak asasi manusia tersebut, setiap warga negara memiliki kewajiban untuk melindungi hak asasi orang lain.

Penjelasan Peraturan Pemerintah Pengganti Undang-Undang Nomor 2 Tahun 2017 Tentang Perubahan Atas Undang-Undang Nomor 17 Tahun $2013 \quad$ Tentang Organisasi Kemasyarakatan Menjadi Undang-Undang, sebagaimana dijelaskan dalam Penjelasan Atas Undang-Undang Nomor 17 Tahun 2013 Tentang Organisasi Kemasyarakatan, menegaskan Pancasila merupakan dasar dan falsafah dalam kehidupan bermasyarakat, berbangsa, dan bernegara. Oleh karena itu, setiap warga Negara, baik secara individu maupun kolektif, termasuk Organisasi Kemasyarakatan (Ormas) wajib menjadikan Pancasila sebagai napas, jiwa, dan semangat dalam mengelola Ormas. Pengakuan dan penghormatan terhadap Pancasila dan UndangUndang Dasar Negara Republik Indonesia Tahun 1945 sebagai dasar dan falsafah berbangsa dan bernegara, tetap menghargai dan menghormati kebhinnekaan Ormas yang memiliki asas perjuangan organisasi yang tidak bertentangan dengan Pancasila, dan begitu pula Ormas yang menjadikan Pancasila sebagai asas organisasinya. ${ }^{3}$

Pergaulan internasional membawa konsekuensi terjadinya interaksi antara organisiasi kemasyarakatan (Ormas) di suatu

\footnotetext{
${ }^{3}$ Penjelasan Atas Undang-Undang Nomor 17
} Tahun 2013 Tentang Organisasi Kemasyarakatan. 
negara dan negara lain. Kehadiran ormas dari negara lain di Indonesia harus tetap menghormati kedaulatan Negara Kesatuan Republik Indonesia, memberi manfaat bagi masyarakat, bangsa dan negara, serta tetap menghormati nilai sosial budaya masyarakat, patuh dan tunduk pada hukum yang berlaku di Indonesia. Oleh karena itu, undang-undang mengatur Ormas yang didirikan warga negara asing dan badan hukum asing yang beroperasi di Indonesia.

Kedudukan organisasi kemasyarakatan yang didirikan oleh warga negara asing memerlukan pengawasan oleh pemerintah agar tidak melakukan kegiatan yang bertentangan dengan ketentuan peraturan perundang-undangan yang berlaku di negara Republik Indonesia.

Hukum adalah produk pemerintah atau penyelenggara negara atau lembaga yang memiliki wewenang untuk itu yang kemudian menjadi hukum positif atau peraturan yang mengikat kehidupan masyarakat dalam aktivitas sosial, ekonomi, politik dan budaya. Hukum mengendalikan dan bersifat mencegah terjadinya tindakan kriminal atau mengatur hubungan antarindividu sehingga dengan adanya hukum itu, gejolak sosial dan mobilitasnya dapat dikendalikan. ${ }^{4}$ Kehadiran hukum dalam masyarakat di antaranya adalah untuk mengintegrasikan suatu kekuasan dan mengkoordinasikan kepentingan-kepentingan yang bisa bertubrukan satu sama lain itu oleh hukum diintegrasikan sedemikian rupa sehingga tubrukan-tubrukan itu bisa ditekan sekecil-kecilnya. Pengorganisasian kepentingankepentingan itu dilakukan dengan mambatasi dan melindungi kepentingan-kepentingan tersebut. Memang dalam suatu lalu-lintas kepentingan, perlindungan terhadap kepentingan-kepentingan tertentu hanya dapat dilakukan dengan cara membatasi kepentingan di lain pihak. ${ }^{5}$

Apabila masyarakat dapat hidup damai, tenteram dan aman maka kehidupan mereka perlu diatur dengan sebaik-baiknya. Mengatur kehidupan masyarakat perlu kaidah-kaidah yang mengikat setiap anggota masyarakat agar tidak terjadi kejahatan dan pelanggaran

\footnotetext{
${ }^{4}$ Wawan Muhwan Hariri. Pengantar IImu Hukum, Cet. 1. CV. Pustaka Setia Bandung. 2012.hlm. 19.

${ }^{5}$ Satjipto Rahardjo, Ilmu Hukum, Cetakan ke- IV, PT. Citra Aditya Bakti, Bandung, 2006, hlm. 53.
}

terhadap ketertiban umum. Dalam hal ini hukum pidana sangat besar artinya bagi kehidupan masyarakat, sebab hukum pidana adalah: hukum yang mengatur tentang kejahatan dan pelanggaran terhadap kepentingan umum dan perbuatan tersebut diancam dengan pidana yang merupakan suatu penderitaan. ${ }^{6}$

\section{B. RUMUSAN MASALAH}

Bagaimanakah pengawasan terhadap organisasi kemasyarakatan yang didirikan oleh warga negara asing ?

\section{METODE PENELITIAN}

Metode penelitian yang digunakan untuk menyusun penulisan ini ialah metode penelitian hukum normatif dengan menggunakan datadata sekunder yang diperoleh dari studi kepustakaan. Data sekunder terdiri atas bahanbahan hukum primer, sekunder dan tersier. Bahan hukum primer berupa peraturan perundang-undangan yang mengatur mengenai organisasi kemasyarakatan. Bahan hukum sekunder berupa literatur-literatur dan karyakarya ilmiah hukum dan bahan hukum tersier dan juga seperti kamus-kamus umum dan kamus-kamus hukum.

Bahan hukum tersier adalah bahan yang dapat membantu memberikan penjelasan dalam memahami bahan hukum primer dan sekunder. ${ }^{7}$

Penelitian hukum normatif mengkaji kelembagaan hukum yang meliputi lembaga eksekutif, legislatif, yudikatif, dan institusi lainnya. Penelitian hukum normatif juga mengkaji subjek hukum yang meliputi badan hukum, organisasi profesi hukum, pelaksana undang-undang, aparat penegak hukum, profesional hukum, kedudukan, fungsi dan peran subjek hukum. ${ }^{8}$

Penelitian hukum yang dilakukan dengan cara meneliti bahan pustaka atau data sekunder belaka, dapat dinamakan penelitian hukum normatif atau penelitian hukum kepustakaan (di samping adanya penelitian

\footnotetext{
${ }^{6}$ Sudarsono, Pengantar IImu Hukum, Cetakan Kelima, PT. Rineka Cipta, Jakarta, 2007, hlm. 209

${ }^{7}$ Soerjono Soekanto, Pengantar Penelitian Hukum, UI Press, Jakarta, 2005, hlm. 52.

${ }^{8}$ Abdulkadir Muhamad, Hukum dan Penelitian Hukum, PT. Citra Aditya Bakti, Bandung. 2004, hlm. 104.
} 
hukum sosiologis atau empiris yang terutama meneliti data primer). ${ }^{9}$

Nama lain dari penelitian hukum normatif adalah penelitian hukum doktriner, juga disebut sebagai penelitian perpustakaan atau studi dokumen. Disebut penelitian hukum doktriner, karena penelitian ini dilakukan atau ditujukan hanya pada peraturan-peraturan yang tertulis atau bahan hukum lain. Dikatakan sebagai penelitian kepustakaan ataupun studi dokumen disebabkan penelitian ini lebih banyak dilakukan terhadap data yang bersifat sekunder yang ada diperpustakaan. ${ }^{10}$

\section{PEMBAHASAN \\ PENGAWASAN TERHADAP ORGANISASI KEMASYARAKATAN YANG DIDIRIKAN OLEH WARGA NEGARA ASING}

Pergaulan internasional membawa konsekuensi terjadinya interaksi antara Ormas di suatu negara dan negara lain. Kehadiran Ormas dari negara lain di Indonesia harus tetap menghormati kedaulatan Negara Kesatuan Republik Indonesia, memberi manfaat bagi masyarakat, bangsa dan negara, serta tetap menghormati nilai sosial budaya masyarakat, patuh dan tunduk pada hukum yang berlaku di Indonesia. Oleh karena itu, Undang-Undang mengatur Ormas yang didirikan warga negara asing dan badan hukum asing yang beroperasi di Indonesia. ${ }^{11}$

Peraturan Pemerintah Nomor 2 Tahun 2007 Tentang Tata Cara Memperoleh, Kehilangan, Pembatalan, Dan Memperoleh Kembali Kewarganegaraan Republik Indonesia. Pasal 1 angka 2. Orang Asing adalah orang yang bukan Warga Negara Republik Indonesia.

Undang-Undang Nomor 16 Tahun 2017 Tentang Penetapan Peraturan Pemerintah Pengganti Undang.Undang Nomor 2 Tahun 2017 Tentang Perubahan Atas Undang-Undang Nomor 17 Tahun 2013 Tentang Organisasi Kemasyarakatan Menjadi Undang-Undang. Pasal 43 ayat:

\footnotetext{
${ }^{9}$ Soerjono Soekanto dan Sri Mamudji, Penelitian Hukum Normatif Suatu Tinjauan Singkat, PT Raja Grafindo Persada, Jakarta. 1995, hlm. 13-14.

${ }^{10}$ Suratman, $\mathrm{H}$ dan Philips Dillah, Metode Penelitian Hukum, Alfabeta, Bandung, 2012, hlm. 51.

${ }^{11}$ Penjelasan Atas Undang-Undang Nomor 17 Tahun 2013 Tentang Organisasi Kemasyarakatan.
}

(1) Ormas yang didirikan oleh warga negara asing dapat melakukan kegiatan di wilayah Indonesia.

(2) Ormas yang didirikan oleh warga negara asing sebagaimana dimaksud pada ayat (1) terdiri atas:

a. badan hukum yayasan asing atau sebutan lain;

b. badan hukum yayasan yang didirikan oleh warga negara asing atau warga negara asing bersama warga negara Indonesia; atau

c. badan hukum yayasan yang didirikan oleh badan hukum asing.

Undang-Undang Nomor 16 Tahun 2017 Tentang Penetapan Peraturan Pemerintah Pengganti Undang. Undang Nomor 2 Tahun 2017 Tentang Perubahan Atas Undang-Undang Nomor 17 Tahun 2013 Tentang Organisasi Kemasyarakatan Menjadi Undang-Undang. Pasal 48. Dalam melaksanakan kegiatannya, ormas sebagaimana dimaksud dalam Pasal 43 ayat (2) wajib bermitra dengan Pemerintah dan Ormas yang didirikan oleh warga negara Indonesia atas izin Pemerintah. Pasal 49. Pembentukan tim perizinan sebagaimana dimaksud dalam Pasal 44 ayat (3) dan Pasal 47 ayat (1) dikoordinasikan oleh menteri yang menyelenggarakan urusan pemerintahan di bidang luar negeri.

Pasal 50. Ketentuan lebih lanjut mengenai perizinan, tim perizinan, dan pengesahan ormas yang didirikan oleh warga negara asing sebagaimana dimaksud dalam Pasal 43 sampai dengan Pasal 49 diatur dalam Peraturan Pemerintah.

Pasal 51. Ormas yang didirikan oleh warga negara asing sebagaimana dimaksud dalam Pasal 43 ayat (2) berkewajiban:

a. menghormati kedaulatan Negara Kesatuan Republik Indonesia;

b. tunduk dan patuh pada ketentuan peraturan perundangundangan;

c. menghormati dan menghargai nilai-nilai agama dan adat budaya yang berlaku dalam masyarakat Indonesia;

d. memberikan manfaat kepada masyarakat, bangsa, dan negara Indonesia;

e. mengumumkan seluruh sumber, jumlah, dan penggunaan dana; dan

f. membuat laporan kegiatan berkala kepada Pemerintah atau Pemerintah Daerah dan 
dipublikasikan kepada masyarakat melalui media massa berbahasa Indonesia.

Pasal 52. Ormas yang didirikan oleh warga negara asing sebagaimana dimaksud dalam Pasal 43 ayat (2) dilarang:

a. melakukan kegiatan yang bertentangan dengan ketentuan peraturan perundangundangan;

b. mengganggu kestabilan dan keutuhan Negara Kesatuan Republik Indonesia;

c. melakukan kegiatan intelijen;

d. melakukan kegiatan politik;

e. melakukan kegiatan yang mengganggu hubungan diplomatik;

f. melakukan kegiatan yang tidak sesuai dengan tujuan organisasi;

g. menggalang dana dari masyarakat Indonesia; dan

h. menggunakan sarana dan prasarana instansi atau lembaga pemerintahan.

Penjelasan Pasal 52 huruf (d) Yang dimaksud dengan "kegiatan politik" adalah kegiatan yang mengganggu stabilitas politik dalam negeri, penggalangan dana untuk jabatan politik, atau propaganda politik. Huruf (h) Yang dimaksud dengan "sarana dan prasarana pada instansi atau lembaga Pemerintahan", antara lain kantor, kendaraan dinas, pegawai, dan peralatan dinas.

Badan Usaha Ormas, diatur pada Pasal 39 ayat:

(1) Dalam rangka memenuhi kebutuhan dan keberlangsungan hidup organisasi, Ormas berbadan hukum dapat mendirikan badan usaha.

(2) Tata kelola badan usaha sebagaimana dimaksud pada ayat (1) diatur dalam AD dan/atau ART.

(3) Pendirian badan usaha sebagaimana dimaksud pada ayat (1) dilaksanakan sesuai dengan ketentuan peraturan perundangundangan.

UUD 1945 Pasal 28 menyatakan Kemerdekaan berserikat dan berkumpul, mengeluarkan pikiran dengan lisan dan tulisan dan sebagainya ditetapkan dengan undangundang". Pasal 28 E ayat (3) Setiap orang berhak atas kebebasan berserikat, berkumpul, dan mengeluarkan pendapat. Ketetapan Majelis Permusyawaratan Rakyat Republik Indonesia Nomor XVII /MPR/1998 tentang Hak Asasi Manusia. Pasal 14. Setiap orang berhak atas kebebasan menyatakan pikiran dan sikap sesuai hati nurani. Pasal 19. Setiap orang berhak atas kemerdekaan berserikat, berkumpul, dan mengeluarkan pendapat.

Undang-Undang Nomor 39 Tahun 1999 tentang Hak Asasi Manusia, Pasal 23 ayat (1) Setiap orang bebas untuk memilih dan mempunyai keyakinan politiknya. Ayat (2) Setiap orang bebas untuk mempunyai, mengeluarkan dan menyebarluaskan pendapat sesuai hati nuraninya, secara lisan dan atau tulisan melalui media cetak maupun elektronik dengan memperhatikan nilai-nilai agama, kesusilaan, ketertiban, kepentingan umum, dan keutuhan bangsa. ${ }^{12}$

Pasal 24 ayat (1) Setiap orang berhak untuk berkumpul, berapat, dan berserikat untuk maksud-maksud damai. Ayat (2) Setiap warga negara atau kelompok masyarakat berhak mendirikan partai politik, lembaga swadaya masyarakat atau organisasi lainnya untuk berperan serta dalam jalannya pemerintahan dan penyelenggaraan negara sejalan dengan tuntutan perlindungan, penegakan, dan pemajuan hak asasi manusia sesuai dengan ketentuan peraturan perundangundangan.

Dasar pertimbangan diberlakukannya Peraturan Pemerintah Republik Indonesia Nomor 59 Tahun 2016 Tentang Organisasi Kemasyarakatan Yang Didirikan Oleh Warga Negara Asing, dinyatakan pada bagian "Menimbang":

a. bahwa organisasi kemasyarakatan yang didirikan oleh warga negara asing di Indonesia perlu menghormati kedaulatan Negara Kesatuan Republik Indonesia, memberi manfaat bagi masyarakat, bangsa dan negara, serta tetap menghormati nilai sosial budaya masyarakat, patuh dan tunduk pada hukum yang berlaku di Indonesia;

b. bahwa untuk menciptakan tertib administrasi penyelenggaraan organisasi kemasyarakatan yang didirikan oleh warga negara asing di Indonesia sebagaimana dimaksud dalam huruf a, perlu mengatur mengenai pemberian perizinan, tim perizinan, dan pertimbangan pengesahan badan hukum organisasi kemasyarakatan yang didirikan oleh warga negara asing serta

\footnotetext{
12 Undang-Undang Nomor 39 Tahun 1999 tentang Hak
} Asasi Manusia. 
tata cara pengenaan sanksi bagi organisasi kemasyarakatan berbadan hukum yayasan asing atau sebutan lain sebagaimana diatur dalam Pasal 44 sampai dengan Pasal 49 dan Pasal 79 Undang-Undang Nomor 17 Tahun 2013 tentang Organisasi Kemasyarakatan;

c. bahwa berdasarkan pertimbangan sebagaimana dimaksud dalam huruf a dan huruf $b$, perlu menetapkan Peraturan Pemerintah tentang Organisasi Kemasyarakatan yang Didirikan oleh Warga Negara Asing. ${ }^{13}$

Peraturan Pemerintah Nomor 59 Tahun 2016 tentang Organisasi Kemasyarakatan Yang Didirikan Oleh Warga Negara Asing merupakan turunan dari Undang-undang Nomor 17 Tahun 2013. Dalam Undang-Undang Nomor 17 Tahun 2013 tersebut ketentuan tentang organisasi masyarakat yang didirikan oleh warga negara asing diatur dalam BAB XIII Pasal 43-52. Kemudian di atur lebih lanjut dalam Peraturan pemerintah Nomor 59 Tahun 2016 yang merupakan peraturan pelaksana dari UndangUndang Nomor 17 Tahun 2013 semakin mengukuhkan legalitas keberadaan ormas asing di Indonesia. ${ }^{14}$

Keberadaan ormas asing yang dikukuhkan dengan Undang-Undang Nomor 17 Tahun 2013 dan di kuatkan dengan keluarnya Peraruran Pemerintah Nomor 59 Tahun 2016 membuat masyarakat mengkhawatirkan terjadinya gangguan stabilitas keamanan negara. Memang hakikat keberadaan Organisasi Masyarakat adalah untuk mengakomodasi kepentingan masyarkat sebagai wadah aspirasi, ide, gagasan, gerakan, dan sebagainya dan memang dalam sejarahnya memang keberadaan Organisasi masyarakat memberikan konstribusi yang cukup besar bagi NKRI, mulai dari zaman Pergerakan dengan berdirinya Boedi Utomo, yang merupakan cikal bakal organisasi masyarakat yang pada akhirnya melahirkan semangat persatuan dan kebersamaan

\footnotetext{
${ }^{13}$ Peraturan Pemerintah Republik Indonesia Nomor 59 Tahun 2016 Tentang Organisasi Kemasyarakatan Yang Didirikan Oleh Warga Negara Asing.

${ }^{14}$ Elwidarifa Marwenny1 Engrina Fauzi dan Jelisye Putri Cenery. Kedudukan Organisasi Kemasyarakatan Asing Di Indonesia Di Tinjau Dari Peraturan Pemerintah Nomor 59 Tahun 2016. Jurnal Cendekia Hukum: Vol. 3, No 2, Maret 2018.P-ISSN: 2355-4657. E-ISSN: 2580-1678.hlm. 207.
}

sehingga negara Indonesia bisa berdiri tegak hingga hari ini. ${ }^{15}$

Peraturan Pemerintah Republik Indonesia Nomor 58 Tahun 2016 Tentang Pelaksanaan Undang-Undang Nomor 17 Tahun 2013 Tentang Organisasi Kemasyarakatan. Pasal 3 ayat:

(1) Ormas dapat berbentuk:
a. badan hukum; atau
b. tidak berbadan hukum.

(2) Ormas berbadan hukum sebagaimana dimaksud pada ayat (1) huruf a dapat berbentuk perkumpulan atau yayasan. ${ }^{16}$

Peraturan Pemerintah Republik Indonesia Nomor 59 Tahun 2016 Tentang Organisasi Kemasyarakatan Yang Didirikan Oleh Warga Negara Asing. Pasal 2 ayat:

(1) Ormas yang didirikan oleh warga negara asing dapat melakukan kegiatan di wilayah Indonesia.

(2) Ormas yang didirikan oleh warga negara asing sebagaimana dimaksud pada ayat (1) terdiri atas:

a. badan hukum yayasan asing atau sebutan lain;

b. badan hukum yayasan yang didirikan oleh warga negara asing atau warga negara asing bersama warga negara Indonesia; atau

c. badan hukum yayasan yang didirikan oleh badan hukum asing. ${ }^{17}$

Untuk dapat disebut sebagai badan hukum harus memenuhi unsur:

1. Harus ada harta kekayaan terpisah dari kekayaan pribadi anggotanya.

2. Harus ada kepentingan yang diakui dan dilindungi oleh hukum, dan kepentingan yang dilindungi itu harus bukan kepentingan satu orang atau beberapa orang saja.

3. Meskipun kepentingan itu tidak terletak pada orang-orang tertentu, namun kepentingan itu harus stabil, artinya tak terikat pada suatu waktu yang pendek saja, tetapi untuk jangka waktu yang panjang.

4. Harus dapat ditunjukkan suatu harta kekayaan yang tersendiri.

\footnotetext{
${ }^{15} \mathrm{Ibid}$.

${ }^{16}$ Peraturan Pemerintah Republik Indonesia Nomor 58 Tahun 2016 Tentang Pelaksanaan Undang-Undang Nomor 17 Tahun 2013 Tentang Organisasi Kemasyarakatan.

${ }^{17}$ Peraturan Pemerintah Republik Indonesia Nomor 59 Tahun 2016 Tentang Organisasi Kemasyarakatan Yang Didirikan Oleh Warga Negara Asing.
} 
5. Mempunyai tujuan tertentu.

6. Mempunyai kepentingan sendiri.

7. Adanya organisasi yang teratur. ${ }^{18}$

Setelah keluarnya Peraturan Pemerintah (PP) Nomor 59 Tahun 2016 tentang Organisasi Masyarakat (Ormas) yang didirikan warga negara asing (WNA) muncul, persoalan ormas kembali mengemuka. Meskipun Wakil Presiden Jusuf Kalla menyatakan bahwasanya masyarakat tidak perlu khawatir dengan keberadaan PP ini karena pemerintah akan tetap memberikan sanksi sekiranya melanggar ketentuan undang-undang, namun masyarakat tetap saja tidak dapat menerimanya karena ditakutkan keberadaan ormas asing di Indonesia membawa agenda terselubung yang merugikan Indonesia. ${ }^{19}$

PP Nomor 59 Tahun 2016 tentang Organisasi Masyarakat (Ormas) tersebut menyebutkan bahwasanya ormas asing yang dapat melakukan kegiatan di wilayah Indonesia adalah badan hukum yayasan asing atau sebutan lain, badan hukum yayasan yang didirikan oleh warga negara asing bersama warga negara Indonesia, atau badan hukum yayasan yang didirikan oleh badan hukum asing. ${ }^{20}$

Dalam PP ini diatur mengenai, pemberian perizinan, tim perizinan, dan pertimbangan pengesahan badan hukum, serta tata cara pengenaan sanksi bagi ormas berbadan hukum yayasan asing atau sebutan lain. PP ini mendapat tanda tangan presiden pada 2 Desember 2016 di mana ormas ini terdiri atas badan hukum yayasan asing atau sebutan lain yang mengelola dana secara mandiri dan badan hukum yayasan asing atau sebutan lain yang melaksanakan program kegiatan dari lembaga donor asing. Dalam PP ini dijelaskan bahwasanya organisasi yang didirikan oleh warga negara asing ini dapat mengajukan penugas kepada 3 orang yang memiliki 3 kewarganegaraan asing untuk bekerja pada

\footnotetext{
${ }^{18}$ Iwan Permadi. Kedudukan Badan Hukum Asing Dalam Pemilikan Tanah Di Indonesia.Wacana- Vol. 15, No. 4 (2012). ISSN : 1411-0199. E-ISSN : 2338-1884.hlm. 42.

${ }^{19}$ Elwidarifa Marwenny1 Engrina Fauzi dan Jelisye Putri Cenery. Op.Cit. hlm.201. (Lihat Waspadai Ormas Asing, tersedia di

http://www.republika.co.id/berita/koran/fokuspublik/16/12/30/oizqc625-waspadai-ormas-asing, di akses tanggal 22 Agustus 2017).

${ }^{20}$ lbid. hlm. 201.
}

ormas asing ini. Meskipun perjanjian tertulis dan ketentuan bahwasanya mereka harus tunduk pada peraturan perundang-undangan harus dilaksanakan namun kekhawatiran masyarakat masih tetap ada. Seorang guru besar dari Universitas Indonesia Maswadi Rauf mempertanyakan alasan Jokowi memberikan izin untuk orang asing agar dapat mendirikan ormas di Indonesia sedangkan ideologinya berbeda, Maswadi mengkhawatirkan timbulnya bahaya dalam ketahanan Indonesia yang menurutnya masih lemah terhadap ancaman dari luar. ${ }^{21}$

Undang-Undang Nomor 16 Tahun 2017 Tentang Penetapan Peraturan Pemerintah Pengganti Undang. Undang Nomor 2 Tahun 2017 Tentang Perubahan Atas Undang-Undang Nomor 17 Tahun 2013 Tentang Organisasi Kemasyarakatan Menjadi Undang-Undang. Pasal 53 ayat:

(1) Untuk meningkatkan kinerja dan akuntabilitas Ormas atau ormas yang didirikan oleh warga negara asing sebagaimana dimaksud dalam Pasal 43 ayat (2) dilakukan pengawasan internal dan eksternal.

(2) Pengawasan internal terhadap Ormas atau ormas yang didirikan oleh warga negara asing sebagaimana dimaksud pada ayat (1) dilakukan sesuai dengan mekanisme organisasi yang diatur dalam AD/ART.

(3) Pengawasan eksternal sebagaimana dimaksud pada ayat (1) dilakukan oleh masyarakat, Pemerintah, dan/atau Pemerintah Daerah.

Pasal 54 ayat:

(1) Untuk menjamin terlaksananya fungsi dan tujuan Ormas, setiap Ormas atau ormas yang didirikan oleh warga negara asing sebagaimana dimaksud dalam Pasal 43 ayat (2) memiliki pengawas internal.

(2) Pengawas internal sebagaimana dimaksud pada ayat (1) berfungsi untuk menegakkan kode etik organisasi dan memutuskan pemberian sanksi dalam internal organisasi.

\footnotetext{
21 Ibid. hlm. 201 (Lihat http://www.voaislam.com/read/politikindonesia/2016/12/19/47976/jokowi-tandatangani-pp59/2016-tentang-ormas-yang-didirikanwna/\#sthash.340xsMH0.dpbs, di akses tanggal 22 Agustus 2017).
} 
(3) Tugas dan kewenangan pengawas internal sebagaimana dimaksud pada ayat (1) diatur dalam $A D$ dan ART atau peraturan organisasi.

Pasal 55 ayat:

(1) Bentuk pengawasan oleh masyarakat sebagaimana dimaksud dalam Pasal 53 ayat (3) dapat berupa pengaduan.

(2) Pengaduan sebagaimana dimaksud pada ayat (1) disampaikan kepada Pemerintah atau Pemerintah Daerah.

Pasal 56. Ketentuan lebih lanjut mengenai pengawasan oleh masyarakat, Pemerintah dan/atau Pemerintah Daerah terhadap Ormas atau ormas yang didirikan oleh warga negara asing sebagaimana dimaksud dalam Pasal 53 sampai dengan Pasal 55 diatur dalam Peraturan Pemerintah.

Secara teknis, hal-hal yang diatur oleh Peraturan Pemerintah Nomor 59 Tahun 2016 adalah perizinan organisasi masyarakat yang didirikan oleh warga negara asing dan sanksinya jika melanggar ketentuan yang berlaku, lebih tepatnya sanksi administrasi berupa: peringatan tertulis, penghentian kegiatan, pembekuan izin operasional, pencabutan izin operasional, pembekuan izin prinsip, pencabutan izin prinsip dan sanksi ke imigrasian sesuai dengan peraturan perundangundangan yang berlaku. Dalam faktanya memang mengatur tentang bagaimana memberikan batasan administrasi terhadap organisasi masyarakat yang didirikan warga asing, namun ketentuan tersebut belumlah mampu menjadi jaminan keamanan negara. ${ }^{22}$

Dengan pertimbangan bahwa organisasi kemasyarakatan yang didirikan oleh warga negara asing (WNA) di Indonesia perlu menghormati kedaulatan Negara Kesatuan Republik Indonesia, memberi manfaat bagi masyarakat, bangsa dan negara, serta tetap menghormati nilai sosial budaya masyarakat, patuh dan tunduk pada hukum yang berlaku di Indonesia, pemerintah memandang perlu mengatur mengenai pemberian perizinan, tim perizinan, dan pertimbangan pengesahan badan hukum, serta tata cara pengenaan sanksi bagi organisasi kemasyarakatan berbadan hukum yayasan asing atau sebutan lain. Atas pertimbangan tersebut, maka pada 2 Desember

\footnotetext{
${ }^{22}$ Elwidarifa Marwenny1 Engrina Fauzi dan Jelisye Putri Cenery. Op.Cit. hlm. 208.
}

2016, Presiden Joko Widodo telah menandatangani Peraturan Pemerintah (PP) Nomor 59 Tahun 2016 tentang Organisasi Kemasyarakatan Yang Didirikan Oleh Warga Negara Asing. ${ }^{23}$

Dalam PP itu disebutkan, Organisasi Kemasyarakatan (Ormas) yang didirikan oleh warga negara asing dapat melakukan kegiatan di wilayah Indonesia. Ormas sebagaimana dimaksud terdiri atas:

a. badan hukum yayasan asing atau sebutan lain;

b. badan hukum yayasan yang didirikan oleh warga negara asing atau warga negara asing bersama warga negara Indonesia; atau

c. badan hukum yayasan yang didirikan oleh badan hukum asing.

Ormas badan hukum yayasan asing atau sebutan lain sebagaimana dimaksud terdiri atas:

a. badan hukum yayasan asing atau sebutan lain yang mengelola dana secara mandiri; dan

b. badan hukum yayasan asing atau sebutan lain yang melaksanakan program kegiatan dari lembaga donor asing.

Menurut PP ini, Ormas badan hukum yayasan asing atau sebutan lain wajib memiliki izin Pemerintah Pusat. ${ }^{24}$

Kementerian Dalam Negeri (Kemendagri) mengingatkan pemerintah daerah untuk meningkatkan perannya mengawasi aktivitas organisasi kemasyarakatan (ormas) yang didirikan warga negara asing (WNA) agar dapat memberikan kemaslahatan yang lebih besar pada masyarakat dan tidak sampai mengancam kedaulatan negara. Pemerintah berkewajiban mengatur keberadaan ormas asing agar keberadaannya tidak melanggar hak kebebasan komponen bangsa lainnya, menjaga ketenteraman dan kepentingan umum, stabilitas dan ideologi negara. Keberadaan ormas yang semakin kompleks, membutuhkan pengaturan dan pengelolaan yang lebih komprehensif, menurut Sekretaris Ditjen Politik dan Pemerintahan Umum Kementerian Dalam Negeri Didi Sudiana saat membuka Rakornas Penanganan Aktivitas Ormas yang Didirikan

\footnotetext{
23 https://setkab.go.id/Inilah PP Tentang Organisasi Kemasyarakatan Yang Didirikan WNA di Indonesia. Diakses 8/16/2019 3:27 Wita.

${ }^{24}$ Ibid.
} 
oleh WNA, di Kuta, Kabupaten Badung, Senin $(24 / 6) .{ }^{25}$

Menteri Hukum dan HAM Yasonna Laoly mengatakan, organisasi kemasyarakatan (Ormas) asing harus tunduk pada peraturan hukum di Indonesia. Hal itu disampaikan Yasonna Laoly menanggapi pengesahan Peraturan Pemerintah (PP) Nomor 59 Tahun 2016 tentang Organisasi Kemasyarakatan Yang Didirikan Oleh Warga Negara Asing oleh Presiden, pada 2 Desember 2016. Undangundang Ormas sudah ada, makanya ini dibuatkan PP-nya untuk mentekniskan undangundang itu, supaya Ormas yang didirikan WNA itu tertib dan tunduk pada aturan di Indonesia. Langkah ini dilakukan pemerintah untuk mengantisipasi potensi penyelewengan oleh ormas asing di Indonesia. ${ }^{26}$

Peraturan Pemerintah Republik Indonesia Nomor 58 Tahun 2016 Tentang Pelaksanaan Undang-Undang Nomor 17 Tahun 2013 Tentang Organisasi Kemasyarakatan. Pasal angka 1. Organisasi Kemasyarakatan yang selanjutnya disebut Ormas adalah organisasi yang didirikan dan dibentuk oleh masyarakat secara sukarela berdasarkan kesamaan aspirasi, kehendak, kebutuhan, kepentingan, kegiatan, dan tujuan untuk berpartisipasi dalam pembangunan demi tercapainya tujuan Negara Kesatuan Republik Indonesia yang berdasarkan Pancasila. Pasal 1 angka 10. Pengawasan adalah salah satu fungsi manajemen untuk menjamin agar kinerja Ormas berjalan sesuai dengan tujuan dan fungsi Ormas sesuai dengan peraturan perundang-undangan. ${ }^{27}$

Dalam suatu negara hukum, pengawasan terhadap tindakan pemerintahan dimaksudkan agar pemerintah dalam menjalankan aktivitasnya sesuai dengan norma-norma hukum, sebagai suatu upaya preventif, dan juga dimaksudkan untuk mengembalikan pada situasi sebelum terjadinya pelanggaran normanorma hukum, sebagai upaya represif. Di

\footnotetext{
25 https://kesbangpol.bantenprov.go.id/ Kemendagri Ingatkan Pemda Tingkatkan Pengawasan Ormas Asing. Diakses 8/16/2019 4:06 Wita.

26 https://nasional.kompas.com/Menkumham Imbau Ormas Asing Patuhi Aturan Hukum di Indonesia. Diakses 8/16/2019 4:00 Wita.

${ }^{27}$ Peraturan Pemerintah Republik Indonesia Nomor 58 Tahun 2016 Tentang Pelaksanaan Undang-Undang Nomor 17 Tahun 2013 Tentang Organisasi Kemasyarakatan.
}

samping itu, yang terpenting adalah bahwa pengawasan ini diupayakan dalam rangka memberikan perlindungan hukum bagi masyarakat. Pengawasan adalah salah satu yang bersifat kodrati. Pengawasan diperlukan dalam kehidupan manusia dan dalam kehidupan organisasi. ${ }^{28}$ Pengawasan dilakukan bukan karena kurang kepercayaan atau untuk mencari-cari siapa yang salah. Tetapi untuk memahami apa yang salah demi perbaikan di masa yang akan datang. Jika pengawasan seperti itu terlaksana, maka semua perencanaan dan peraturan akan berjalan dengan baik, dalam artian tidak ada gangguan dan rongrongan terhadap pelaksanaannya. Hal ini akan menciptakan suasanan tenang, aman dan berkeadilan. ${ }^{29}$

Pengawasan adalah segenap kegiatan untuk meyakinkan dan menjamin bahwa pekerjaan-pekerjaan dilakukan sesuai dengan rencana yang telah ditetapkan, kebijaksanaankebijaksanaan yang telah digariskan dan perintah-perintah yang telah diberikan dalam rangka pelaksanaan rencana tersebut. ${ }^{30}$

Hukum bekerja dengan cara mengatur perbuatan seseorang atau hubungan antara orang-orang dalam masyarakat. Untuk keperluan pengaturan tersebut, maka hukum menjabarkan pekerjaannya dalam berbagai fungsinya yaitu:

1. Pembuatan norma-norma, baik yang memberikan peruntukan maupun yang menentukan hubungan antara orang dengan orang;

2. Penyelesaian sengketa-sengketa;

3. Menjamin kelangsungan kehidupan masyarakat, yaitu dalam hal terjadi perubahan-perubahan. ${ }^{31}$

Undang-Undang Nomor 16 Tahun 2017 Tentang Penetapan Peraturan Pemerintah Pengganti Undang. Undang Nomor 2 Tahun 2017 Tentang Perubahan Atas Undang-Undang Nomor 17 Tahun 2013 Tentang Organisasi

\footnotetext{
${ }^{28}$ Sarwoto. Dasar-dasar Organisasi dan Manajemen, Ghalia Indonesia. Jakarta. 1994. hlm. 9.

${ }^{29}$ Ibid.

${ }^{30}$ Nawawi Hadari. Pengawasan Melekat di Lingkungan Aparatur Pemerintah. Gelora Aksara Pratama, Jakarta. 1992. hlm. 7.

${ }^{31}$ Satjipto Raharjo. Hukum dan Perubahan Sosial Suatu Tinjauan Teoretis Serta Pengalaman-Pengalaman di Indonesia. Cetakan Ketiga Genta Publishing. Yogyakarta. 2009. hlm. 111.
} 
Kemasyarakatan Menjadi Undang-Undang. Pasal 61 ayat:

(1) Sanksi administratif sebagaimana dimaksud dalam Pasal 60 ayat (1) terdiri atas:

a. peringatan tertulis;

b. penghentian kegiatan; dan/atau

c. pencabutan surat keterangan terdaftar atau pencabutan status badan hukum.

(2) Terhadap Ormas yang didirikan oleh warga negara asing sebagaimana dimaksud dalam Pasal 43 ayat (2) selain dikenakan sanksi administratif sebagaimana dimaksud pada ayat (1) huruf a dan huruf b juga dikenakan sanksi keimigrasian sesuai dengan ketentuan peraturan perundang-undangan. Pasal 60 ayat:

(1) Ormas yang melanggar ketentuan sebagaimana dimaksud dalam Pasal 21, Pasal 51, dan Pasal 59 ayat (1) dan ayat (2) dijatuhi sanksi administratif.

(2) Ormas yang melanggar ketentuan sebagaimana dimaksud dalam Pasal 52 dan Pasal 59 ayat (3) dan ayat (4) dijatuhi sanksi administratif dan/atau sanksi pidana.

Pasal 43 ayat (2) Ormas yang didirikan oleh warga negara asing sebagaimana dimaksud pada ayat (1) terdiri atas: a. badan hukum yayasan asing atau sebutan lain; b. badan hukum yayasan yang didirikan oleh warga negara asing atau warga negara asing bersama warga negara Indonesia. Pasal 21. Ormas berkewajiban:

a. melaksanakan kegiatan sesuai dengan tujuan organisasi;

b. menjaga persatuan dan kesatuan bangsa serta keutuhan Negara Kesatuan Republik Indonesia;

c. memelihara nilai agama, budaya, moral, etika, dan norma kesusilaan serta memberikan manfaat untuk masyarakat;

d. menjaga ketertiban umum dan terciptanya kedamaian dalam masyarakat;

e. melakukan pengelolaan keuangan secara transparan dan akuntabel; dan

f. berpartisipasi dalam pencapaian tujuan negara.

Pasal 59 ayat (1) Ormas dilarang: a. menggunakan nama, lambang, bendera, atau atribut yang sama dengan nama, lambang, bendera, atau atribut lembaga pernerintahan; b. menggunakan dengan tanpa izin nama, lambang, bendera negara lain atau lembaga/badan internasional menjadi narna, lambang, atau bendera Ormas; dan/atau c. menggunakan n€una, lambang, bendera, atau tanda gambar yang mempunyai persamaan pada pokoknya atau keseluruhannya dengan nama, lambang, bendera, atau tanda gambar Ormas lain atau partai politik.

Pasal 59 ayat (3) Ormas dilarang: a. melakukan tindakan pennusuhan terhadap suku, agama, ras, atau golongan; b. melakukan penyalahgunaan, penistaan, atau penodaan terhadap agama yang dianut di Indonesia; c. melakukan tindakan kekerasan, mengganggu ketenteraman dan ketertiban umum, atau merusak fasilitas umum dan fasilitas sosial; dan/atau d. melakukan kegiatan yang menjadi tugas dan wewenang penegak hukum sesuai dengan ketentuan peraturan perundangundangan. Ayat (4) Ormas dilarang: a. menggunakan nama, lambang, bendera, atau simbol organisasi yang mempunyai persamaan pada pokoknya atau keseluruhannya dengan nama, lambang, bendera, atau simbol organisasi gerakan separatis atau organisasi terlarang; b. melakukan kegiatan separatis yang mengancam kedaulatan Negara Kesatuan Republik Indonesia; dan/atau c. menganut, mengembangkan, serta menyebarkan ajaran atau paham yang bertentangan dengan Pancasila.

Kedudukan organisasi kemasyarakatan yang didirikan oleh warga negara asing telah memberikan kepastian hukum bagi warga negara asing untuk dapat mendirikan organisasi kemasyarakatan tetapi wajib untuk menaati peraturan perundang-undangan yang berlaku di Indonesia. Pemerintah wajib melakukan pengawasan terhadap organisasi kemasyarakatan yang didirikan oleh warga negara asing guna untuk meningkatkan kinerja dan akuntabilitas dan tidak melakukan kegiatan yang bertentangan dengan ketentuan peraturan perundang-undangan yang berlaku.

\section{PENUTUP}

1. Pengawasan terhadap organisasi kemasyarakatan yang didirikan oleh warga negara asing dilakukan untuk meningkatkan kinerja dan akuntabilitas ormas yang didirikan oleh warga negara asing maka dilakukan pengawasan internal dan eksternal. Pengawasan internal terhadap 
ormas yang didirikan oleh warga negara asing dilakukan sesuai dengan mekanisme organisasi yang diatur dalam anggaran dasar/anggaran rumah tangga. Pengawasan eksternal dilakukan oleh masyarakat, pemerintah, dan/atau pemerintah daerah.

2. Pelaksanaan pengawasan terhadap organisasi kemasyarakatan yang didirikan oleh warga negara asing memerlukan dukungan masyarakat melalui upaya berupa pengaduan yang dapat disampaikan kepada pemerintah atau pemerintah daerah, apabila diketahui ada organisasi kemasyarakatan yang didirikan oleh warga negara asing melakukan pelanggaran atas ketentuan-ketentuan dalam UndangUndang Nomor 17 Tahun 2013 Tentang Organisasi Kemasyarakatan.

\section{DAFTAR PUSTAKA}

Elwidarifa Marwenny Engrina Fauzi dan Jelisye Putri Cenery. Kedudukan Organisasi Kemasyarakatan Asing Di Indonesia Di Tinjau Dari Peraturan Pemerintah Nomor 59 Tahun 2016. Jurnal Cendekia Hukum: Vol. 3, No 2, Maret 2018.P-ISSN: 2355-4657. E-ISSN: 2580-1678.

Hadjon M. Philipus.. Pengantar Hukum Administrasi Indonesia. Gadjah Mada University Press, Yogyakarta 1994.

Hamzah Andi, Terminologi Hukum Pidana, (Editor) Tarmizi, Ed. 1. Cet. 1. Sinar Grafika, Jakarta, 2008.

Hariri Muhwan Wawan. Pengantar IImu Hukum, Cet. 1. CV. Pustaka Setia Bandung. 2012.

H. Suratman, dan Philips Dillah, Metode Penelitian Hukum, Alfabeta, Bandung, 2012.

Muhamad Abdulkadir, Hukum dan Penelitian Hukum, PT. Citra Aditya Bakti, Bandung. 2004.

Permadi Iwan. Kedudukan Badan Hukum Asing Dalam Pemilikan Tanah Di Indonesia.Wacana-Vol. 15, No. 4 (2012). ISSN : 1411-0199. E-ISSN : 2338-1884.

Raharjo Satjipto. Hukum dan Perubahan Sosial Suatu Tinjauan Teoretis Serta Pengalaman-Pengalaman
Indonesia. Cetakan Ketiga Genta Publishing. Yogyakarta. 2009.

Sarwoto. Dasar-dasar Organisasi dan Manajemen, Ghalia Indonesia. Jakarta. 1994.

Soekanto Soerjono dan Sri Mamudji, Penelitian Hukum Normatif Suatu Tinjauan Singkat, PT Raja Grafindo Persada, Jakarta. 1995.

Sutedi Adrian. Hukum Perizinan Dalam Sektor Pelayanan Publik, Sinar Grafika. Jakarta. 2011.

Syahrin Alvi, Beberapa Isu Hukum Lingkungan Kepidananaan, Cetakan Revisi, PT. Sofmedia, Jakarta, 2009.

Tutik Triwulan Titik, Pokok-pokok Hukum Tata Negara Indonesia Pasca Amandemen UUD 1945, Cerdas Pustaka.

Winayanti Karnia Nia, Dasar Hukum Pendirian \& Pembubaran Ormas (Organisasi Kemasyarakatan), Cetakan 1. Pustaka Yustisia, Yogyakarta. 2011.

Yamin Muhammad, Tindak Pidana Khusus, Cet. 1. Pustaka Setia, Bandung, 2012.

\section{Peraturan Perundang-Undangan}

Undang-Undang Nomor 39 Tahun 1999 tentang Hak Asasi Manusia.

Undang-Undang Nomor 17 Tahun 2013 Tentang Organisasi Kemasyarakatan.

Peraturan Pemerintah Republik Indonesia Nomor 58 Tahun 2016 Tentang Pelaksanaan Undang-Undang Nomor 17 Tahun 2013 Tentang Organisasi Kemasyarakatan.

Peraturan Pemerintah Republik Indonesia Nomor 59 Tahun 2016 Tentang Organisasi Kemasyarakatan Yang Didirikan Oleh Warga Negara Asing.

\section{Internet}

https://setkab.go.id/Inilah PP Tentang Organisasi Kemasyarakatan Yang Didirikan WNA di Indonesia. Diakses 8/16/2019 3:27 Wita.

https://kesbangpol.bantenprov.go.id/

Kemendagri Ingatkan Pemda Tingkatkan Pengawasan Ormas Asing. Diakses 8/16/2019 4:06 Wita.

https://nasional.kompas.com/Menkumham Imbau Ormas Asing Patuhi Aturan Hukum di Indonesia. Diakses 8/16/2019 4:00 Wita. 